\title{
ROLE OF HYPERBILIRUBINAEMIA - A NEW DIAGNOSTIC TOOL AND A PREDICTOR OF GANGRENOUS/PERFORATED APPENDICITIS
}

\author{
R. Rajavelu', V. Udhayasankar ${ }^{2}$ \\ ${ }_{1}^{1}$ Professor, Department of General Surgery, Government Vellore Medical College, Vellore, Tamilnadu. \\ 2Junior Resident, Department of General Surgery, Government Vellore Medical College, Vellore, Tamilnadu.
}

\section{ABSTRACT}

\section{BACKGROUND}

Acute Appendicitis is one of the most common surgical emergency encountered in a day-to-day surgical practice and in emergency. Delay in diagnosis and treatment can lead to gangrene, perforation and diffuse peritonitis.

The aim of this study is to find out the specificity, sensitivity, predictive value of positive test and predictive value of negative test of Serum Bilirubin in diagnosis of acute appendicitis and acute complicated appendicitis.

\section{MATERIALS AND METHODS}

All the patients admitted with clinical diagnosis of Acute Appendicitis were tested by laboratory investigations and ultrasonography of the abdomen. Preoperatively, patient's blood was also collected for serum bilirubin and other liver enzymes estimation. Cases that underwent emergency appendicectomy from August 2015 - August 2016 were included in present Prospective Analytical Study.

\section{RESULTS}

About 100 patients were included in this prospective analytical study. Hyperbilirubinaemia as a sensitivity of $84.7 \%$ and specificity of $80 \%$, predictive value of positive test is $96 \%$ and predictive value of negative test is $48 \%$. In complicated appendicitis that is gangrenous/perforated appendicitis, the serum bilirubin levels are higher compared to acute appendicitis.

\section{CONCLUSION}

The level of serum bilirubin aids in the diagnosis of Acute Appendicitis and higher levels as a predictive potential for the Acute Complicated Appendicitis (Gangrenous/Perforated).

\section{KEYWORDS}

Serum Bilirubin, Acute Appendicitis, Acute Complicated Appendicitis.

HOW TO CITE THIS ARTICLE: Rajavelu R, Udhayasankar V. Role of hyperbilirubinaemia - a new diagnostic tool and a predictor of gangrenous/perforated appendicitis. J. Evolution Med. Dent. Sci. 2017;6(5):358-360, DOI: 10.14260/Jemds/2017/81

\section{BACKGROUND}

Acute appendicitis is the most common surgical emergency seen in day-to-day practice in emergency department. ${ }^{1}$ It can sometimes confuse the practitioners by its presentation. The delay in early diagnosis or failure in early diagnosis may happen many times. ${ }^{2}$ This may lead on to the poor disease prognosis. This will further lead on to increase in morbidity as well as occasional mortality in the patient, though there are many recent trends in investigatory modalities.

Diagnosis of acute appendicitis is still a mystery. There is increase in the negative appendicectomy rate of about $15 \%$ - 30\% seen in literature. ${ }^{3}$

So number of various investigations were used to reduce the rate of negative appendicectomy such as Laboratory investigations and Radiological investigations. ${ }^{4}$

Financial or Other, Competing Interest: None.

Submission 08-12-2016, Peer Review 30-12-2016,

Acceptance 09-01-2017, Published 16-01-2017.

Corresponding Author:

Dr. R. Rajavelu,

\#9, $5^{\text {th }}$ Cross,

Gandhi Nagar West,

Vellore-632006.

E-mail: rvstanley@gmail.com

DOI: $10.14260 /$ jemds $/ 2017 / 81$

\section{Objectives}

To find out the specificity, sensitivity, predictive value of positive test and predictive value of negative test of serum bilirubin in diagnosis of acute appendicitis and acute complicated appendicitis.

\section{MATERIALS AND METHODS}

This study was conducted as Prospective Analytical Study.

This study was conducted in 100 patients. These 100 patients are clinically diagnosed to have acute appendicitis and who underwent emergency appendicectomy. This study conducted in Govt. Vellore Medical College Hospital, Vellore, Department of General Surgery, during the period from August 2015 to August 2016.

Serum bilirubin of more than $1.6 \mathrm{mg} / \mathrm{dL}$ considered high and more than $2.2 \mathrm{mg} / \mathrm{dL}$ considered very high.

\section{Inclusion Criteria}

All the patients above 15 years of age diagnosed to have appendicitis included in this study and subjected for appendicectomy in Govt. Vellore Medical College, Vellore.

\section{Exclusion Criteria}

Patients who were HBsAg positive, patients taking hepatotoxic drugs, where serum bilirubin was raised.

- Sensitivity = TP X $100 / \mathrm{TP}+\mathrm{FN}$.

- $\quad$ Specificity $=\mathrm{TN}$ X $100 / \mathrm{TN}+\mathrm{FP}$.

- $\quad$ Predictive Value of Positive Test $=$ TP X $100 /$ TP + FP. 
- Predictive Value of Negative Test $=$ TN X $100 /$ TN + FN

\section{RESULTS}

100 patients were included in this study and underwent Emergency Appendicectomy.

\section{Age Distribution}

The acute appendicitis fall into 5 groups in the study population. In this study, maximum incidence is seen in $3^{\text {rd }}$ decade of life, that is the age group between 21 and 30 years followed by the age group between 31 and 40 yrs., least incidence of appendicitis occurrence was seen in $>50$ years' age group shown in Table 1.

\begin{tabular}{|c|c|c|}
\hline Age (Years) & Incidence (Out of 100) & Percentage \\
\hline $15-20$ & 22 & $22 \%$ \\
\hline $21-30$ & 35 & $35 \%$ \\
\hline $31-40$ & 27 & $27 \%$ \\
\hline $41-50$ & 11 & $11 \%$ \\
\hline$>50$ yrs. & 5 & $5 \%$ \\
\hline Total & $\mathbf{1 0 0}$ & $\mathbf{1 0 0} \%$ \\
\hline \multicolumn{3}{|c|}{ Table 1. Age Distribution } \\
\hline
\end{tabular}

\section{Sex Distribution}

In our study, the number of male patients are 55 and female patients are 45 in number.

\begin{tabular}{|c|c|c|c|}
\hline \multirow{2}{*}{$\begin{array}{c}\text { Serum } \\
\text { Bilirubin }\end{array}$} & \multicolumn{2}{|c|}{ HPE } & \multirow{2}{*}{ Total } \\
\cline { 2 - 3 } Positive & Negative & \\
\hline \multirow{2}{*}{ Positive } & 72 & 3 & \multirow{2}{*}{75} \\
& TP & FP & \\
\hline \multirow{2}{*}{ Negative } & 13 & 12 & \multirow{2}{*}{25} \\
& FN & TN & \\
\hline Total & $\mathbf{8 5}$ & $\mathbf{1 5}$ & $\mathbf{1 0 0}$ \\
\hline \multicolumn{3}{|c|}{ Table 2. Role of Serum Bilirubin } \\
\hline
\end{tabular}

Table 2 depicts,

In the present study, out of 100 patients 85 patients had HPE positive, among 85 positive individuals, serum bilirubin was raised in 72 patients that is $84.7 \% ; 13$ patients had normal serum bilirubin value $(\mathrm{x} 2 \mathrm{McNemor}=8.9, \mathrm{P}=<0.01)$, significant association in diagnosis of acute appendicitis.

In this study among 14 complicated patients, 13 patients had very high raise in serum bilirubin value $92 \%$, whereas only 1 patient had very high serum bilirubin value in an uncomplicated appendicitis.

In present study serum bilirubin shows specificity of $80 \%$, predictive value of positive test $96 \%$ and negative predictive value of $48 \%$.

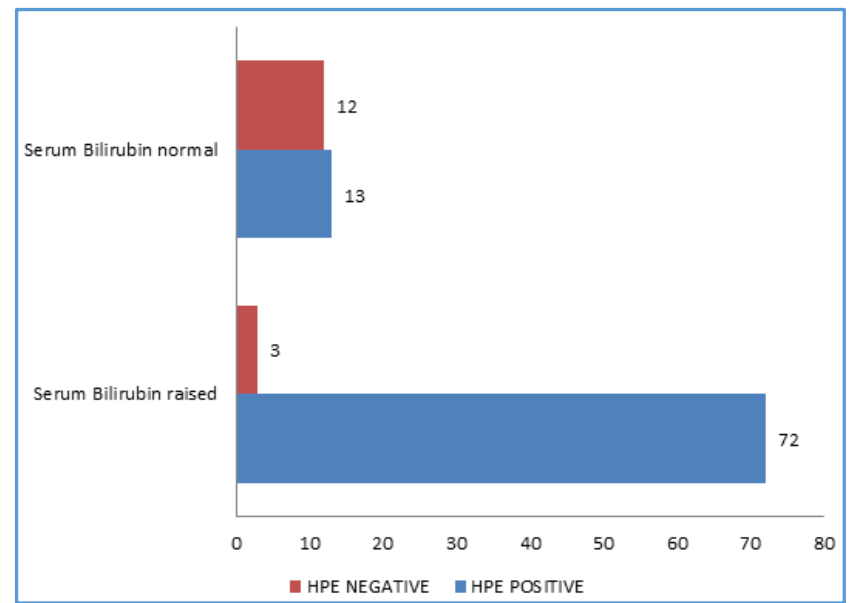

Figure 1. Serum Bilirubin with HPE Correlation

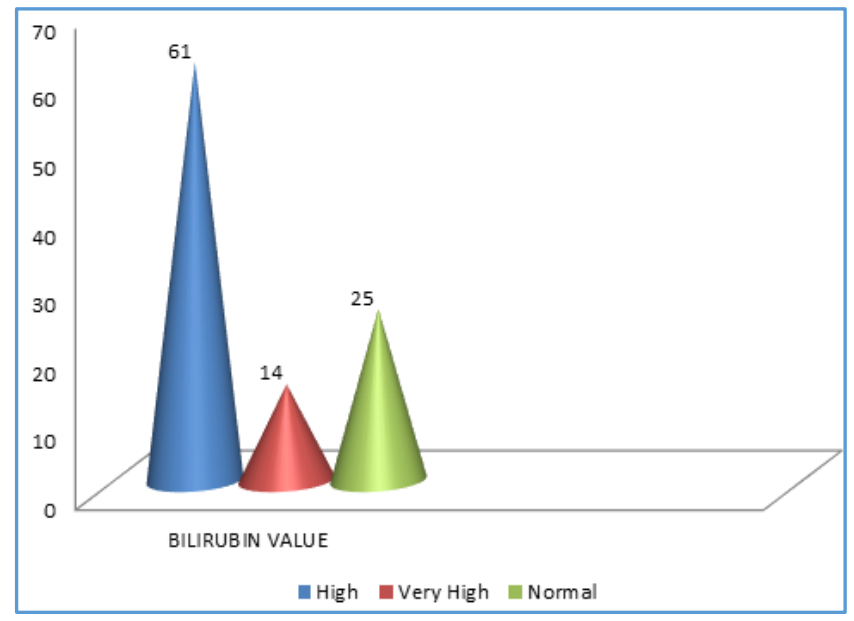

Figure 2. Distribution of Cases according to Serum Bilirubin Value

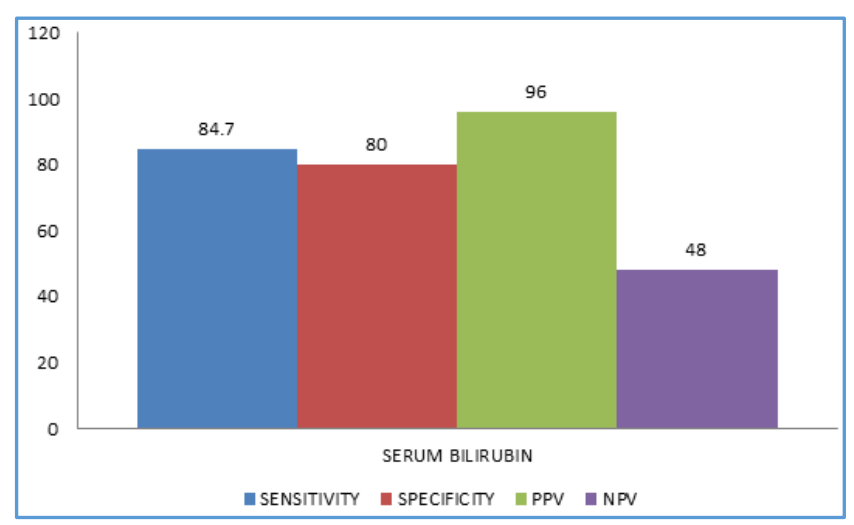

Figure 3. Sensitivity, Specificity, Predictive Value of Positive Test and Negative Test of Serum Bilirubin

\section{DISCUSSION}

In this study it reveals that serum bilirubin is highly sensitive in diagnosis of complicated appendicitis, sensitivity of $92 \%$. The sensitivity of serum bilirubin increase in uncomplicated appendicitis is $84.7 \%$. 
The interesting finding of this study was that the positive predictive value was $96 \%$, which aids in the diagnosis of acute appendicitis. If the serum bilirubin goes beyond $>2.2$ $\mathrm{mg} / \mathrm{dL}$, the possibility of complicated appendicitis is very high.

Bilirubin is not commonly known to be a relevant marker in appendicitis. However, previous studies have found hyperbilirubinaemia to be a marker with high specificity for perforated appendicitis. Adult bilirubin levels in the adult surgical population are usually raised due to liver or gallbladder problems. ${ }^{5}$

Hepatic dysfunction as a result of bacterial infection or sepsis without direct invasion of the liver has already been well described. The possible aetiologies include gram negative sepsis, shock and ischaemic liver, severe trauma or gut barrier failure. Gram negative organisms with Escherichia coli in particular have been shown to produce endotoxins that affect bile flow in rat liver models. None of the patients in our study had ischaemic liver or septic shock.6,7

In appendicitis, compromised appendix wall integrity leads to translocation of bacteria and endotoxins from the appendix lumen into the portal system. Inflammatory cytokines may then travel to the liver inducing intrahepatic cholestasis. Research has also shown that E. coli endotoxin causes dose dependent cholestasis, which would explain our findings of increased bilirubin levels with progressive appendicitis severity. It is possible that bilirubin may be raised in other sources of gram-negative related sepsis, which may be of a gastrointestinal origin (E. coli in diverticulitis) or from other sources such as pneumonia, endocarditis, pyelonephritis and soft-tissue abscesses. ${ }^{8}$

Estrada et al, ${ }^{9} 2007$ in his retrospective study of 170 patients with findings of hyperbilirubinaemia (17.1 mmol/L) and perforated appendicitis $\mathrm{p}<0.031$, Odds ratio of 2.96 (95\% confidence interval 1.11e7.6).

Sand et al,10 2009 in his retrospective study of 538 patients with Hyperbilirubinaemia $(26.5 \mathrm{mmol} / \mathrm{L})$ and perforated appendicitis $\mathrm{p}<0.05$, specificity $86 \%$.

Kaser et al,11 2010 in his retrospective study of 725 patients with Hyperbilirubinaemia $(20 \mathrm{mmol} / \mathrm{L})$ and perforated appendicitis $\mathrm{p}<0.05$ and specificity $78 \%$.

Atahan et al,12 2011 in his retrospective study of 351 patients with Hyperbilirubinaemia (17.1 mmol/L) and perforated appendicitis $\mathrm{p}=0.000$ and specificity $87.21 \%$.

Emmanuel et al,13 2011 in his Retrospective study of 472 patients with hyperbilirubinaemia ( $20.5 \mathrm{mmol} / \mathrm{L})$ and simple appendicitis $\mathrm{p}<0.001$, specificity $88 \%$ Hyperbilirubinaemia and perforated appendicitis $\mathrm{p}<0.001$, Specificity $70 \%$.

Beltran et al,14 2009 in his Prospective study of 134 patients Hyperbilirubinaemia (17.86 mmol/L) and perforated appendicitis Specificity $51 \%$ and Sensitivity $57 \%$.

Khan et al,15 2004 observed among 110 individuals the serum bilirubin value was increased in acute appendicitis; it is more specifically elevated in complicated appendicitis. Specificity of this study in complicated appendicitis is $80.6 \%$, in uncomplicated acute appendicitis 56.36\%.

\section{CONCLUSION}

Bilirubin is a specific marker for acute appendicitis with a good positive predictive value. It is also a valuable indicator of patients more likely to have appendiceal perforation or gangrene. Bilirubin should be used together with clinical examination and other laboratory investigations in the assessment of patients with suspected acute appendicitis.

\section{REFERENCES}

[1] Peranteau WH, Smink DS. Appendix, Meckel's and other small bowel diverticula. In: Zinner MJ, Stanley AW, (eds). Maingot's abdominal operation. $12^{\text {th }}$ edn. New York: The McGraw-Hill Companies 2013:623-40.

[2] Alvarado A. A practical score for the early diagnosis of acute appendicitis. Ann Emerg Med 1986;15(5):557-64.

[3] Chang FC, Hogle HH, Welling DR. The fate of the negative appendix. Am J Surg 1973;126(6):752-4.

[4] Pearson RH. Ultrasonography for diagnosing appendicitis. Br Med J 1988;297(6644):309-10.

[5] Chand N, Sanyal AJ. Sepsis-induced cholestasis. Hepatology 2007;45(1):230-41.

[6] Utili R, Abernathy CO, Zimmerman HJ. Studies on the effects of C. coli endotoxin on canalicular bile formation in the isolated perfused rat liver. J Lab Clin Med 1977;89(3):471-82.

[7] Utili R, Abernathy CO, Zimmerman HJ. Inhibition of $\mathrm{Na}+$, $\mathrm{K}+$-adenosinetriphosphatase by endotoxin: a possible mechanism for endotoxin-induced cholestasis. J Infect Dis 1977;136(4):583-7.

[8] Trauner M, Fickert P, Stauber RE. Inflammation-induced cholestasis. J Gastroenterol Hepatol 1999;14(10):94659.

[9] Estrada JJ, Petrosyan M, Barnhart J, et al. Hyperbilirubinemia in appendicitis: a new predictor of perforation. J Gastrointest Surg 2007;11(6):714-8.

[10] Sand M, Bechara FG, Holland-Letz T, et al. Diagnostic value of hyperbilirubinemia as a predictive factor for appendiceal perforation in acute appendicitis. Am J Emerg Med 2009;198(2):193-8.

[11] Kaser SA, Fankhauser G, Willi N. C-reactive protein is superior to bilirubin for anticipation of perforation in acute appendicitis. Scand J Gastro-enterol 2010;45(78):885-92.

[12] Atahan K, Ureyen O, Aslan E, et al. Preoperative diagnostic role of hyperbilirubinaemia as a marker of appendix perforation. J Int Med Res 2011;39(2):609-18.

[13] Emmanuel A, Murchan P, Wilson I, et al. The value of hyperbilirubinaemia in the diagnosis of acute appendicitis. Ann R Coll Surg Engl 2011;93(3):213-7.

[14] Beltran MA, Mendez PE, Barrera RE, et al. Is hyperbilirubinaemia in appendicitis a better predictor of perforation than C-reactive protein? -a prospective study. Indian J Surg 2009;71(5):265-72.

[15] Khan S. Elevated serum bilirubin in acute appendicitis: a new diagnostic tool. Kathmandu Univ Med J 2008;6(2):161-5. 